1. Батюшков П. Волынь: Исторические судьбы юго - западного края. - Спб : Типография Товарищества «Общественная польза», 1888. - С. 83.

2. Бондаренко Г., Гулько Г., Дем’янюк О. З’їзд монархів у Луцьку: мистецьке відображення. Старий Луцьк. Випуск XIV. - Луцьк : Терези, 2018. - С. 267.

3. Ворончук I. Населення Волині в 16 першій половині 17 ст.: родина, домогосподарство, демографічні чинники. - Київ : Видавництво ППВФ, 2012. - С. 594.

4. Грушевський М. Історія України Руси. Т. IV. XV - XVI віки. - Київ : Наукова думка, 1993. - С. $194-199$.

5. Гваньїні О. Хроніка європейської Сарматії. Упорядкування та переклад з польської о. Юрія Міцика. 2-ге видання, допрацьоване. - Київ : Видавничий дім «Києво-Могилянська Академія», 2009. - 1004 с.

6. Гулько Г. Спогади венеціанського купця Амброджо Контаріні про Луцьк 70-х років XV століття. Старий Луцьк. Випуск XIV. - Луцьк : Терези, 2018. - С. 126.

7. Дем'янюк О., Пасюк I. Воєнна історія Волині. Т.1. Давня доба - кінець XVIII ст. - Луцьк : Вежа - Друк, 2013. - С. 81-87.

8. Кудь О. Луцька війна 1431 року. Минуле і сучасне Волині та Полісся: Луцьк в історії Волині та України. Випуск 35. - Луцьк : Твердиня, 2010. - С. 137.

9. Козлова Г. Александр Гваньини и его сочинения // Гваньини А. Описания Московии. - Москва : Наука. 1997. - С. 7.

10. Олександр Цинкаловський та праісторія Волині / Упоряд. Г. Охріменко - Луцьк : Волинська обласна друкарня, 2008. - С. 177.

11. Русина О. Луцький з'їзд монархів 1429 року. Енциклопедія історії України. Ред. кол. В. Смолій (голова) та ін. Т 6. - Київ : Наукова думка, 2009. - 790 с.

12. Смолій В., Берковський В. та інші. Україна і Литва в 14 - 16 століття. - Луцьк : ПрАТ «Волинська обласна друкарня», 2011. - 252 с.

13. Санников С. Двадцать веков християнства. Второе тисячелетие. Т.2. - Одесса - Спб, 2001. - С.114.

14. Троневич П. Волинь в сутінках української історії XIV - XVI ст. - Луцьк : Місійна фабрика «Християнське життя», 2003. - С. 44-45.

15. Терський С. Історія Луцька. Т.1. Лучеськ X - XV ст. - Львів : Вид-цтво національного університету «Львівська політехніка», 2007. - С. 50.

16. Садовнік Т., Бірюліна О., Баран В. Свропейський з’їзд 1429 року в Луцьку. Друге видання. - Луцьк : Волинська обласна друкарня, 2006. - 32 с.

17. Тищенко К. Італія і Україна: тисячолітні етномовні контакти. - Київ : Аквілон, 2009. - С. 121-122.

18. Шараневич И. Исторія Галицко - Володимирской Руси от найдавнейших времен до року 1453. - Львов, 1863. - С. 356-357.

19. Цинкаловський О. Стара Волинь і Волинське Полісся. Т. 1. - Вінніпег : Т-ство Волинь, 1984. - 600 с.

20. Електронний pecypc: www/history. ua/novyna/ картина - з’їзд- європейських- монархів- у--луцьку.429-рік.htth.

21. Електронний pecypc:E-mail:krion.kiev@ukr.net www.History - ua.org картина - з’їзд - європейських - монархів - у--луцьку.-429-рік.htth.

DOI: https://doi.org/10.32782/2305-9389/2020.21.12

УДК 94(477.8):340.15:339.5

\title{
Оксана Карліна
}

\section{Правове регулювання торгово-промислової діяльності в містах Волинської губернії в кінці XVIII - середині XIX ст.}

На підставі аналізу численних правових актів Російської імперії розкрито державне регулювання торговопромислової діяльності у містах Волинської губернії кіния XVIII cm. - середини XIX cm. Зазначено, які види торгівлі розрізняло законодавство, як нормувалась торгівля за становою ознакою (купиів, міщан і селян), як співвідносилось оподаткування з обсягом торгівлі та видами товарів. Враховано, щзо численні урядові укази, положення, маніфести, постанови, з одного боку, відображають механізм проведення держсавної політики в галузі торгового підприємництва, а з другого боку, у процесі їх підготовки верховна влада, взявщи до уваги реальний стан справ у иій галузі, який ї̈ не задовольняв, намагалася його змінити законодавчим шляхом.

Матрицею для правових нововведень у торгівлі на наступні декілька десятиліть стали правила щодо купецтва, виписані у «Грамоті на права і вигоди містам Російської імперії» 1785 р., які започаткували системний підхід до опису в законах станового статусу купеитва. Маніфесту 1807 р. засвідчив розуміння оновленою бюрократією Олександра I
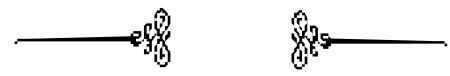
необхідність розвитку комеричї та промисловості. Закон «Про організацію гільдій $і$ про торгівлю інших станів», відомий як гільдійська реформа міністра фінансів Сгора Канкріна, став базовим для регламентачї торгової діяльності купецтвва та інших станів аж до початку Великих реформ 1860-х років. У ході кодифікачій законодавства в 1830-х роках був складений «Звід статутів і установ торгових», в якому містилось визначення торгівлі та окреслена ї̈ структура.

За обсягом товарообігу та асортиментом домінуючою формою торгівлі залишались ярмарки. Їх держава розглядала як один із засобів підвищення платоспроможності платників податків, а тому розширювала привілеї ярмаркового типу торгівлі.

Вивчення правових норм переконливо свідчить, щзо в першій половині ХІХ ст. держава встановила всебічний контроль за торгівлею купчів, міщчан і селян, включаючи обсяг товарів, щчо продавались, час $і$ місие товарообміну, нагляд за вагами; при цььому був витриманий диференційований підхід до різних сочіальних груп.

Глибшого дослідження потребує питання державного регулювання торгово-підприємницької діяльності купиівєвреїв з огляду хоча би на те, иоо саме євреї складали основну масу волинського купецтва в першій половині ХІХ ст.

Ключові слова: Волинська губернія, торгово-промислова діяльність, купецтво, правове регулювання, купецькі гільдї, торговий капітал.

Legal regulation of trade and industrial activity in the cities of Volyn region at the late of XVIII and the middle of XIX

Based on the analysis of numerous legal acts of Russian empire state regulation of trade and industrial activity in the cities of Volyn region at the end of XVIII and the middle of XIX was disclosed. It was indicated which kinds of trade were differentiated by legislation, how the trade was being standardized according to estate feature (merchants, philistines and peasants), how taxation was correlated with amount of trade and kinds of goods. It was taken into account that numerous government decrees, regulations, manifestos, rulings in one hand display the mechanism of state policy' carrying out in the field of the trade entrepreneurship, and in other hand at the process of its preparation the supreme government given the real situation in this field (which did not satisfy it) tried to change it by legal way.

The matrix for legal innovations in trade for the next few decades became the rules for merchants written in the "Charter on the rights and benefits of the cities of the Russian Empire" (1785) which introduced a systematic approach to the description of the estate status of merchants in the laws. The manifesto of 1807 testified to the understanding by the renewed bureaucracy of Alexander I the need to develop commerce and industry. The Law "Ab out the organization of guilds and trade of other estates" known as the Guild Reform of Finance Minister Yehor Kankrin became the basis for regulating the trade activities of merchants and other estates until the beginning of Great Reforms in the 1860s. During the codification of legislation in the 1830s, a "Code of trade statutes and institutions" was compiled which contained a definition of trade and outlined its structure.

Fairs remained the dominant form of trade for amount of turnover and range. The state regarded them as one of the ways of increasing the solvency of taxpayers and therefore expanded the privileges of the fair type of trade.

Investigation of legal forms convincingly testifies that in the first part of XIX century the state had established comprehensive control on the trade of merchants, philistines and peasants, including amount of selling goods, time and place of barter processes, weight control, while adhered to differentiated approach to different social groups.

The problem of trade and industrial activity' state regulation of merchants-Jewish requires the deeper researches considering at least that exactly Jewish were the main part of Volyn merchants in the first part of XIX century.

Key words: Volyn region, trade and industrial activity, merchants, state regulation, merchant guilds, trade capital.

Постановка наукової проблеми та її значення. Активний розвиток торговопідприємницької діяльності в країні ставить перед сучасним суспільством низку завдань, розгляд $\mathrm{i}$ вирішення яких вимагає аналізу цього явища 3 урахуванням історичних традицій. Усе, що пов'язано з підприємництвом, має сьогодні практичне значення, оскільки дозволяє пояснити деякі сучасні перспективи його розвитку.

Торгово-підприємницька діяльність на Волині має тривалий шлях свого розвитку, кожний етап характеризується специфічними рисами. Одним 3 таких етапів є кінець XVIII - середина XIX ст. - період інтенсифікації процесу первісного нагромадження капіталу в межах політики жорсткого державного регулювання торгового i промислового підприємництва. Вивчення правового регулювання торгово-промислової діяльності дозволяє розкрити особливості та суть державної політики. У різних указах, статутах, положеннях та інших законодавчих актах відобразилося розуміння верховною владою важливості торгівлі й підприємництва для розвитку економіки держави загалом, так і окремих регіонів.

Найширші права на ведення підприємницької діяльності отримало купецтво. Разом 3 тим у торгово-промислову діяльність були включені також інші верстви суспільства: дворянство, міщанство, селянство. В умовах станової організації суспільства державно-правове регулювання здійснювалось диференційовано щодо різних соціальних груп.

Аналіз досліджень цієї проблеми. Державне правове регулювання торгових операцій в Російській імперії практично не вивчалось у ХІХ ст. На початку 1890-х років управитель Варшавської казенної палати I. Я. Рудченко, за дорученням спеціальної державної комісії,
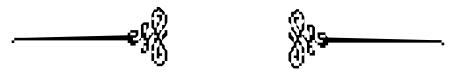
створеної з метою підготовки матеріалів для перегляду законодавства щодо оподаткування внутрішньої торгівлі, підготував дослідження еволюції законодавчої бази Російської імперії в галузі оподаткування торгівлі та промисловості, починаючи з торгових зборів Київської Русі аж до XIX ст. [38]. У 1901 р. юрист і публіцист Г. С. Вольтке дав коротку характеристику торгового права для кожного стану і різних категорій населення Російської імперії, зробивши висновок, що Торговий статут, який діяв в першій половині XIX ст., був проникнутий духом станової винятковості [2].

У радянській історіографії правове становище купецтва докладно розглянуто в роботі П. Г. Риндзюнського. У його книзі викладена динаміка росту державного оподаткування купців в останній третині XVIII і першій чверті XIX ст. [39]. Цим же істориком також проаналізована Гільдійська реформа 1824 р. Є. Ф. Канкріна [40].

Однією з грунтовних робіт з історії торгівлі на українських землях у першій половині XIX ст. залишається монографія Івана Гуржія, в якій автор розглянув проникнення товарно-грошових відносин у сільське господарство, розгортання торгівлі хлібом та худобою, розвиток ярмаркової та постійної торгівлі в містах [11]. Дослідницький інтерес Б. Кругляка був пов’язаний з різними проблемами розвитку внутрішньої торгівлі в Україні в 60-90-х рр. ХІХ ст. [18; 19].

За останні роки появилось чимало робіт українських дослідників 3 історії торгівлі та купецтва. Організацію та ведення хлібної торгівлі на українських землях у ХІХ ст. прослідковано в книжці О. Гордуновського [7]. Поглиблене вивчення цієї теми шляхом розширення часових меж представлено в монографії О. Гордуновського, О. Гуржія та О. Реєнта [8]. В іншій роботі ці ж автори основну увагу звернули «на роль і місце різних станів і соціальних груп у розвитку національної торгівлі, «виходу» іï на зарубіжжя», також визначили «етнічний склад і майнову нерівність реалізаторів різноманітної продукції» [9]. У статтях Д. Решетченка охарактеризовано внутрішній хлібний ринок та наголошено на переорієнтації хлібної торгівлі Правобережної України з північно-західного на південний [36; 37]. Міжнародний транзит товарів через українські землі в першій половині XIX ст. був предметом вивчення в кількох роботах Т. Гончарука. Особливу увагу він приділив транзитному маршруту Одеса - Броди та функціонуванню одеського порто-франко [4; 5; 6].

У дослідженнях О. Доніка проаналізований правовий та соціальний статус купецтва України в Російській імперії протягом усього XIX ст., показано зміни у чисельності, етно-конфесійному складі купців, розкриті напрями їхньої діяльності, участь у міському самоврядуванні, станових $\mathrm{i}$ професійних організаціях [15; 16; 17]. Деякі проблеми формування купецького стану в Україні розглянуто в роботі О. Гуржія [12]. Окреме дослідження О. Гуржія та І. Гуржій присвячене купецтву Києва і Київщини XVII-XIX ст. [13], де серед інших питань автори розглянули організаційні засади ведення торгівлі та підприємництва у цьому місті.

Для розуміння політики імперської влади щодо торгової діяльності купецтва важливе значення має вивчення системи оподаткування. Податкова політика Російської імперії в Україні в дореформений період проаналізована в дослідженні В. Орлика [35]. Серед широкого кола питань, розглянутих автором, ним також охарактеризовано гільдії як важливий фінансовий інститут.

Отже, в історичній літературі відсутні спеціальні дослідження, в яких би комплексно аналізувався процес державно-правового регулювання торгово-підприємницької діяльності наприкінці XVIII - першій половині XIX ст. Разом з тим в історіографії нагромаджений чималий матеріал, який так чи інакше розкриває деякі аспекти теми в межах досліджень загального характеру або робіт, присвячених конкретним питанням історичного розвитку торгівлі.

Мета: розглянути, як проходило загальне регулювання торгівлі у зазначених хронологічних межах, які види торгівлі розрізняло законодавство, як регулювалась торгівля за становою ознакою, тобто щодо купців, міщан і селян; як співвідносилось оподаткування з обсягом торгівлі та видами товарів. Джерельну базу розвідки склали нормативно-правові акти, які регламентували ведення торгівлі в містах Волинської губернії та опубліковані в «Полном собрании законов Российской империи».

При аналізі законодавства взято до уваги, що правові акти відображали суспільні процеси, адже «закони створюються як механізм для проведення певної урядової політики. Саме тому текст закону виступає [...] як умовна система координат, яка вказує, з однієї сторони, що хотіли б мати
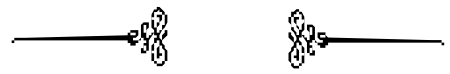
урядові структури, як створювачі законів, а з іншої, уряд відштовхується від реального становища, яке перестає задовольняти найвищі органи державної влади і управління» [42, с. 6].

Виклад основного матеріалу й обгрунтування отриманих результатів дослідження. Після приєднання Волині до складу Російської імперії розпочався процес пристосування місцевих торговців до ведення торгово-підприємницької діяльності в нових політичних реаліях. Першим законом, яким регулювалась торгівля відповідно до російського законодавства, стала «Грамота на права і вигоди містам Російської імперії» 1785 р. (Жалувана грамота містам) [10]. У розділі «Про гільдії та гільдійські вигоди взагалі» встановлювалось, що купцями є ті, хто записався в гільдію. Для цього потрібно упродовж грудня оголосити наявність капіталу в межах від 1 тис. до 50 тис. рублів і сплатити в цьому ж місяці один відсоток 3 оголошеного капіталу. Запис у гільдію звільняв від сплати подушного податку. У ст. 94 і 95 відмічалось, що «капітал вважається сімейним» і тому діти записаного в гільдію купця, «доки не в поділі», не повинні нічого платити, але треба вказати склад сім’і.

Передбачався поділ на три гільдії залежно від розміру оголошеного капіталу та обсягу торгівлі: для 1-ї гільдії - в межах 10 - 50 тис. рублів, 2-ї - 5-10 тис. рублів, 3-ї - 1-5 тис. рублів. Купцям 1-ї гільдії «не тільки дозволяється, але заохочується вести всякі всередині і поза Імперією торги, товари виписувати і відпускати за море, їх продавати, вимінювати і купувати оптом або вроздріб» (ст. 104). Купці 2-ї гільдії мали право «вести всякі всередині Імперії торги, і товари возити водою і сухопуттю, по містах і ярмарках, і в них продавати, вимінювати і купувати потрібне для їхнього торгу оптом або вроздріб». Купці 3-ї гільдії могли вести «дрібний торг у містах і в повіті, продавати дрібний товар в місті і в окрузі, і цей дрібний товар возити водою і сухопуттю по селах, сільцях і сільських торжках, i на цих торжках продавати, вимінювати i купувати потрібне для дрібного торгу оптом або вроздріб».

Положення про поділ купців, які мали капітал понад 500 рублів, на три гільдії, звільнення їх від подушного податку і встановлення однопроцентного податку з оголошеного капіталу вперше було викладено в маніфесті Катерини II від 17 березня 1775 р. про «дарування різним станам милості» (ст. 47) [20, с. 86]. В сенатському указі від 25 травня 1775 р. встановлювались межі купецьких гільдій [21]. У Жалуваній грамоті містам вони були повторені.

У середині 1794 р. для вступу в першу гільдію нижній поріг був піднятий до 16 тис. рублів, у другу - до 8 тис. рублів, у третю - до 2 тис. рублів [22].

Доказом купецького стану був гільдійський лист, підписаний гільдійським старшиною і двома особами з тієї ж гільдії як свідками.

Замість виконання рекрутської повинності «натурою» 31783 р. купці могли платити по 500 рублів за кожного рекрута [23].

Ця введена за Катерини II кодифікація правил щодо купецтва стала матрицею на наступні декілька десятиліть.

Новим документом, який визначив основні правила ведення торгівлі в першій половині XIX ст., був маніфест від 1 січня 1807 р. за назвою «Про дарування купецтву нових вигід, відзнак, переваг і нових способів до поширення посилення торгових підприємств» [24].

У першому розділі регламентувалося заснування торгових товариств як підприємницьких інституцій. Товариства утворювалися «з двох або багатьох товаришів, в одну і ту ж гільдію записаних, які вирішили разом торгувати під спільною назвою для всіх». Таке товариство називалося торговим домом (ст. 2). Обумовлювалось, що у випадку участі в торговому домі «батька із сином або внуком по сині» (тобто із сином сина) тільки старший у сім'ї повинен платити відсотковий збір з капіталу. Інші ж діти або родичі, будучи товаришами, повинні бути записаними в таку ж гільдію і платити відсотковий збір з капіталу ( ст. 4). Товаришем можна було бути тільки в одному торговому домі, позаяк товариш відповідав за борг дому усім майном.

У другому розділі були виписані права дворян, які займалися комерцією і мали право записуватися в гільдії (тільки в першу та другу), платити податок 3 капіталу і виконувати міські повинності, засновувати торговий дім. При цьому зберігалися усі їхні дворянські права. Якщо закон від 4 листопада 1802 р. надавав дворянам право займатися зовнішньою оптовою торгівлею [26], то маніфест - внутрішньою оптовою торгівлею. 
У третьому розділі були розглянуті права іноземців для заняття торгівлею в Росії. Для вступу в гільдію вони повинні були перейти в російське підданство. Однак законодавство виділяло категорії «гостя» або «купця заїжджого», торгова діяльність яких була обмежена своїм регіоном.

У четвертому розділі, центральному в маніфесті, визначалися права власне купецтва. Підтверджувався поділ на три гільдії і виділення всередині першої гільдії першостатейних (або дійсних) купців. У законі містилось визначення таких купців (ст. 15). Звання «іменитих граждан» для купецтва було відмінено.

Вказувалось, що відміняється рекрутська повинність для всіх трьох гільдій, введена раніше (ст. 17). Підтверджувався збір чверті процента з купецькому капіталу до міських доходів.

Закон відрізняв підрядника, відкупника або дрібного крамаря від справжнього купця. До підрядів і відкупів, де річна сума перевищувала 12 тис. руб., не допускались купці 3-ої гільдії, а де перевищувала 50 тис. руб. - купці 2-ої гільдії.

Значення маніфесту 1807 р. полягало в розумінні оновленою бюрократією Олександра I необхідності розвитку комерції і промисловості. У літературі того і наступного часу маніфест отримав схвальну оцінку. Наприклад, відомий історик права М. В. Варадінов назвав його «знаменитим законоположенням, яке дало новий розвиток нашій торгівлі як предмету, що відноситься власне до Міністерства фінансів» [1, с. 196].

У наступні 15 років були схвалені декілька проміжних указів. Так, указом від 19 серпня 1808 p. дозволялось оголошувати капітал і записуватись у купецтво у будь-який час усім, кому не було заборонено входити в гільдії. Однак у тільки у грудні дозволявся перехід з вищих гільдій у нижчі і лише в цьому місяці міщани і державні селяни могли оголошувати капітал і ставати купцями [29]. 3 метою недопущення несвоєчасної сплати гільдійського податку був прийнятий закон, за яким ті купці, які не внесли процентних грошей протягом грудня, виключалися 3 купецтва та їх записували в міщанство. Займатися торгівлею їм заборонялось [30, с. 609].

Від 1825 р. торгова діяльність регулювалася законом «Про організацію гільдій і про торгівлю інших станів» [34], відомим як Гільдійська реформа Є. Ф. Канкріна, міністра фінансів у 1823-1844 pp. На його підставі запроваджувалися два розряди промислового свідоцтва, які надавали одинакові права, але допускали різний обсяг товарообігу. Свідоцтво першого розряду не обмежувало обсягу торгівлі; за другим вартість однієї партії товарів не могла перевищувати 50 тис. руб., а річний товарообіг - 300 тис. руб. [34, с. 589-590]. Брати казенні підряди і відкупи, укладати приватні договори ці торговці могли лише на суму до 50 тис. руб. Їм заборонялось займатись банківською справою і мати страхові контори. Такі види діяльності закріплювались лише за купцями 1-ої гільдії. Власникам свідоцтва першого і другого розряду дозволялось вести внутрішню і зовнішню торгівлю. Власники свідоцтва третього розряду могли торгувати не тільки в містах, але й у повіті, закупати товари у селян та продавати в місті у роздріб. Свідоцтва перших трьох розрядів мали лише купці.

Свідоцтва четвертого розряду зрівнювали права в торгівлі міщан і селян. Товари, які вони мали право продавати, поділялись на групу «А» $\mathrm{i}$ «Б». У групу «А» входили товари селянського виробництва і деякі дрібні товари; ними можна було торгувати в крамницях, гостинних дворах [34, с. 598-600]. До групи «Б» належали дорожчі товари: бакалійні, так звані «колоніальні».

Власники свідоцтва п'ятого розряду мали право торгувати товарами власного виробництва не у крамницях, а на лотках і столах; ці товари були перелічені у реєстрі під літерою «В». 3 ними вони могли виїжджати на ярмарки і торги [34, с. 600].

Був ще шостий розряд платників промислового свідоцтва - дрібних виробників і торговців. У розмежуванні між п’ятим і шостим розрядом не було чіткості, хоча різниця у ціні свідоцтва була суттєвою: ціна свідоцтва 5-ого розряду - 40 руб., 6-ого - 25 руб. [34, с. 601].

До 1823 р. від міщан, які займались торгівлею і товарообіг при цьому перевищував 1 тис. руб., вимагалось мати відповідне свідоцтво, за яке стягувався збір у розмірі 40 руб. Відповідно до указу від 24 листопада 1824 р. такі міщани отримували статус «торгуючих міщан». Торгівлю вони могли вести у власній або орендованій крамниці.

Торгівля в містечках західних губерній регулювалась тими ж правилами, що й у містах, але «щоб вільні люди та євреї, які в них мешкають, були записані до міста того повіту, де містечко знаходиться» [34, с. 600]. 
Шляхтичі західних губерній, які не мали селян і бажали займатися міськими промислами, мали записатися у купці або взяти свідоцтва «торгуючих міщан».

Контроль за торгівлею і дотриманням правил, визначених законом від 1824 р., покладався на міські думи, ратуші і магістрати. При думах створювались торгові депутації (3-7 осіб) для контролю за торгівлею [34, с. 607].

Також були переглянуті норми оподаткування купецтва. Ціна промислових свідоцтв для купців першої гільдії складала 2200 рублів, другої гільдії - 880 рублів, третьої - 220 рублів; ціна білету на крамницю - 100 рублів для першої та другої гільдій, 75 рублів - для третьої гільдії. Всього ж купець перших двох гільдій повинен був платити кожного року такі податки: гільдійський податок 4 \%, на водні і сухопутні шляхи сполучення по $10 \% 3$ кожного податного рубля, на земські повинності по 0,25 \% 3 капіталу, на міські повинності по 0,25 \% 3 капіталу. Купець третьої гільдії повинен був платити трохи менше, оскільки гільдійський податок складав $2,5 \%$.

Таким чином, розміри гільдійського збору зросли. Вони не змінювалися аж до 1863 р., коли змінився порядок поділу на гільдії. Те, що Гільдійська реформа 1824 р. була базовою для регламентації торгової діяльності купецтва та інших станів у наступні три десятиліття, вважало багато правників XIX-XX ст. Наприклад, на думку Г. С. Вольтке статути, викладені в XI томі Зводу законів видання 1832, 1842 і 1857 рр., були базовані на законі від 14 листопада 1824 р. [2, с. 1].

У 1825-1827 рр. вийшло кілька указів, які дещо змінили пункти Гільдійської реформи 1824 р.: була удвічі знижена плата за свідоцтва для торгуючих міщан [32], для прикажчиків - 380 до 50 руб.; ліквідовані свідоцтва 5-ого і 6-ого розрядів, фактично відмінені переліки товарів, доступних для продажу міщанами; міщани могли торгувати в крамницях [31].

У 1832 р. у складі Зводу законів був виданий Звід статутів державного устрою, друга частина якого називалася «Звід статутів і установ торгових» [41, с. 219-220]. У ньому подано визначення торгівлі та окреслена їі структура. У ст. 1 говорилось: «Торгівля поділяється: 1) за простором торгу, на внутрішню і зовнішню; 2) за кількістю товарів, на оптову, роздрібну і дрібну; 3) за місцем проведення, на торгівлю в містах і селах». 3 посиланням на текст «Додаткової постанови про облаштування гільдій» 1824 р. була викладена ст. 2 Торгового статуту, в якій перелічувалися всі категорії діяльності, що входили, на думку законодавців, у поняття «торгова діяльність». Цих категорій біло шість: «1. Промисловість у побудові, купівлі, ремонті і найму кораблів і купецьких суден та у відправленні їх 2. Купецькі прикази про закупівлю, продаж, перевезення і доставку товарів або так звані справи комісійні, експедиційні і маклерські; 3. Грошові перекази в російські та іноземні міста і всілякі банківські справи, також утримання страхових контор; 4. Вступ у казенні підряди і відкупи; 5. Утримання магазинів, ангарів, складів, крамниць і погребів для складання товарів і продаж їх; також фабрик і заводів будь-яких, за винятком винокурних; утримання трактирних закладів, готелів, ресторанів і постоялих дворів, кавових домів, ренскових погребів, питейних домів, портерних крамниць, харчевень, корчм, рибних садків, торгових бань та інших торгових закладів. 6. Розмін грошей».

Відповідно до законодавства (Законів про стани, Торгового і Митного статутів) за умови оформлення відповідних документів і сплати мита торгівля дозволялась представникам усіх станів. Торгівля заборонялась монахам, священно- і церковнослужителям 3 білого духовенства (але дозволялась їхнім удовам), духовним особам протестантського і вірмено-григоріанського сповідань, особам магометанського духовенства до звільнення або виключення їх 3 духовного звання; дворянам, які знаходились на службі державній або губернській виборній; нижнім військовим чинам, які перебували на дійсній службі, за винятком виробів власного виробництва; євреям-поселенцям; маклерам i нотаріусам (доки вони знаходяться на посаді); митним чиновникам. 31840 р. дворяни і чиновники, котрі перебували на державній службі, мали право володіти крамницями, які знаходить у їхніх житлових будинках [25].

За обсягом товарообігу та асортиментом домінуючою формою торгівлі залишались ярмарки періодичні форми товарообміну. Саме вони регулювати співвідношення між попитом i пропозицією, виробництвом і споживанням, впливаючи тим самим на розвиток різних галузей економіки. 
Відкриття ярмарків регламентувала 29-а стаття Жалуваної грамоти міста 1785 р. , яка давала право дворянам відкривати містах і містечках один ярмарок або більше залежно від обставин, необхідності та зручності для місцевого населення, «з відома генерал-губернаторів і губернських правлінь» [10, с. 348-349].

Після поділу державних справ між міністерствами указом від 17 серпня 1810 р. внутрішня торгівля увійшла в підпорядкування міністерства внутрішніх справ [43, с. 462, № 2810], а контроль за процесом відкриття нових ярмарків і ринків, поліцейським нагляд за порядком на них був доручений господарському департаменту міністерства поліції $[44$, с. 720]. Справи щодо клеймування і продажу нових ваг і мір покладалися на департаменти мануфактур і внутрішньої торгівлі міністерства фінансів [3, с. 324].

У першій половині XIX ст. держава розглядала ярмарки як один із засобів підвищення платоспроможності податного населення, а тому розширювала привілеї ярмаркового типу торгівлі. Про це свідчать указ від 29 травня 1814 р., який встановлював право вільної від мит і різних зборів торгівлі на ярмарках для всіх станів [27]. В уряді розуміли, що обмеження свободи торгівлі здатне зруйнувати саме існування ярмарків, які можуть «нижчим класам торговців дати більше зручностей до підвищення їхнього капіталу», «[...] так і вищим класам сприяти їхнім грошовим оборотам». Ярмарки стали визначатися як загальний ринок, де «[...] вільна торгівля всім станам повинна бути дозволена безперешкодно на час тривання їх», тобто торгівля на ярмарках дозволялась без купівлі торгових свідоцтв і сплати мита. Після завершення часу проведення ярмарка розпродаж товарів повинен був відбуватися за загальними державними постановами. Цим законом ярмаркова торгівля була поставлена у вигідне становище, особливо з уваги на те, що крамнична торгівля в селах була заборонена міським жителям до 1863 p.

Оцінюючи роль ярмарок у розвитку внутрішнього ринку Російської імперії, уряд вважав за потрібне вести облік доходів, які надходили з ярмаркових торгів [28]. 3 цією метою відповідно до вимоги міністра внутрішніх справ 31828 р. відомості про ярмарки, про товари, які на них продавалися, повинні були включатися у щорічні статистичні губернаторські звіти.

Обліку підлягала оренда крамниць, яток, погребів під час ярмарок, які тривали більше трьох днів. Вона мала бути оформлена письмово у вигляді контрактів, білетів на гербовому папері [33].

Висновки й перспективи подальших досліджень. У хронології розвитку законодавства можна виділити декілька базових актів, які дозволяють поділити його на періоди: 1) становлення системного підходу до опису в законах станового статусу купецтва, що було пов'язано із закріпленням у Жалуваній грамоті містам 1785 р. прямого оподаткування та в законі 1794 р. про підвищення збору для вступу у гільдію; 2) маніфест 1807 р., який зафіксував зростання економічної і соціальної ролі купецтва; 3) закон 1824 р., що містив докладний опис комерційної діяльності купецтва.

У законодавстві кінця правління Олександра I очевидне поєднання принципів оподаткування 3 фактом володіння нерухомістю і виділення в цій нерухомості тієї, яка використовується в комерційних цілях (здається в оренду).

Вивчення законодавства про торгівлю показало, що в зазначений період був встановлений контроль за торгівлею, який всебічно охоплював торгову діяльність купців, міщан і селян, включаючи обсяг товарів, що продавались, час і місце торгівлі, нагляд за вагами.

Глибшого дослідження потребує питання державного регулювання торгово-підприємницької діяльності купців-євреїв 3 огляду на те, що саме євреї складали основну масу волинського купецтва в першій половині XIX ст.

\section{Джерела та література}

1. Варадинов Н. В. История Министерства внутренних дел. Санкт-Петербург: тип. Мин-ва внутренних дел, 1858. Ч. 1. [Период первоначального учреждения министерства: с 8 сент. 1802 г. По 1809 г. включительно]. 250, 45, [13] с.

2. Вольтке Г. С. Право торговли и промышленности в России в историческом развитии [XIX век]. СанктПетербург: тип. В. Киршбаума, 1901. 25 с.

3. Высочайше утвержденное разделение государственных дел по министерствам. 1810. Августа 17. ПС3 РИ. Собрание первое. Санкт-Петербург: тип. ІІ Отделения собственной Е. И. В. канцелярии, 1830. Т. XXXI. № 24 326. C. 323-328.
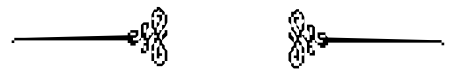
4. Гончарук Т. Г. Одеське порто-франко: Історія. 1819-1859 рр. Одеса: Астропринт, 2005. 312 с.

5. Гончарук Т. Г. Транзит Броди-Одеса в першій половині ХІХ ст.: історико-правовий аспект. Проблеми історії Украӥни XIX-початку XX ст. Київ, 2006. Вип. XII. С. 95-102.

6. Гончарук Т. Г. Транзит західноєвропейських товарів через Наддніпрянську Україну першої половини ХІХ ст.; за ред. О. П. Рента. Одеса: Астропринт, 2008. 280 с.

7. Гордуновський О. М. Організація, розвиток та напрямки хлібної торгівлі в Україні у XIX ст. Черкаси: Брама-Україна, 2010. 320 с.

8. Гордуновський О. М., Гуржій О. І., Реєнт О. П. Український хліб і його реалізація в XVIII - на початку XX ст. (Нариси з історії та економіки). Київ: Інститут історії України НАНУ, 2013. 224 с.

9. Гордуновський О. М., Гуржій О. І., Реєнт О. П. Торгівля в Південній Україні: організація товарообороту та людський потенціал (кінець XVIII - початок XX ст.). Київ: Інститут історії України НАНУ, 2017. 155 с.

10. Грамота на права и выгоды городам Российской империи. 1785. Апреля 21. ПСЗ РИ. Собрание первое. Санкт-Петербург: тип. II Отделения собственной Е. И. В. канцелярии, 1830. Т. ХХІІ. № 16 187. С. $358-$ 384.

11. Гуржій I. О. Розвиток товарного виробництва і торгівлі на Україні (з кінця XVIII ст. до 1861 року). Київ: вид-во АН УРСР, 1962. 205 с.

12. Гуржій О. І. Деякі проблеми становлення купецького стану в Україні. Київ: Ін-т історії України НАН України, 2004. 80 с.

13. Гуржій I. О., Гуржій О. I. Купецтво Києва та Київщина в XVII - XIX ст. Київ: Інститут історії України НАН України, 2013. 284 с.

14. Донік О. М. Соціальний статус купецької верстви в Підросійській Україні наприкінці XVIII - у XIX ст. Проблеми історії Украӥни XIX-початку XX cm. Київ, 2004. Вип. 8. С. 86-108.

15. Донік О. М. Купецтво як стан в Україні (ХІХ ст.). Український історичний журнал. 2006. № 3. С. $16-41$.

16. Донік О. М. Купецтво України імперському просторі (ХІХ ст.). Київ, 2008. 271 с.

17. Донік О. М. Чисельність та етнічно-конфесійний склад купецтва України в XIX - на початку XX ст. Украӥнський історичний журнал. 2009. № 5. С. 73-91.

18. Кругляк Б. А. Торговельна буржуазія в Україні (60-ті роки ХІХ ст. - 1914 р.). Украӥнський історичний журнал. 1994. № 6. С. 72-81.

19. Кругляк Б. А. Внутренняя торговля в России в конце XIX - начале XX века (На материалах Украины). Самара: Изд-во «Самарский университет», 1992. 191 с.

20. О высочайше дарованных разным сословиям милостей по случаю заключения мира с Портой Оттоманскою. Манифест. 1775. Марта 17. ПСЗ РИ. Собрание первое. Санкт-Петербург: тип. ІІ Отделения собственной Е. И. В. канцелярии, 1830. Т. ХХ. № 14 275. С. 82-86.

21. О сборе с купцов вместо подушного по одному проценту с объявленного капитала и о разделении их на гильдии. Сенатский [указ] в следствие именного. 1775. Мая 25. ПСЗ РИ. Собрание первое. СанктПетербург: тип. ІІ Отделения собственной Е. И. В. канцелярии, 1830. Т. ХХ. № 14 327. С. 143-147.

22. О сборе с купечества единовременно в казну с объявленных ими капиталов по одному проценту со ста; о возвышении капиталов, объявляемых для вступления в гильдию и взыскании в доход казны с купеческих капиталов. Переходящих к наследникам, единовременно по одному проценту. Именной указ, данный Сенату. 1794. Июня 23. ПСЗ РИ. Собрание первое. Санкт-Петербург: тип. ІІ Отделения собственной Е. И. В. канцелярии, 1830. Т. ХХІІІ. № 17 223. С. 331-332.

23. О сборе с купечества вместо рекрут по 500 рублей за каждого рекрута. Именной [указ], данный Сенату. 1783. Мая 3. ПСЗ РИ. Собрание первое. Санкт-Петербург: тип. ІІ Отделения собственной Е. И. В. канцелярии, 1830. Т. ХХІ. № 15 721. С. 906.

24. О дарованных купечеству новых выгодах, отличиях и новых способах к распространению и усилению торговых предприятий. Манифест. 1807. Января 1. ПСЗ РИ. Собрание первое. Санкт-Петербург: тип. II Отделения собственной Е. И. В. канцелярии, 1830. Т. ХХІХ. № 22 418. С. 971-979.

25. О дозволении дворянам и вообще чиновникам, состоящим в государственной службе, владеть в городах лавками, в жилых принадлежащих им домах находящимися. Сенатский [указ]. 1840. Июня 19. ПСЗ РИ. Собрание первое. Санкт-Петербург: тип. II Отделения собственной Е. И. В. канцелярии, 1830. Т. XV. Отделение первое. № 13 568. С. 411.

26. О дозволении помещикам производить заграничную оптовую торговлю. Именной [указ], данный Сенату. 1802. Ноября 4. ПСЗ РИ. Собрание первое. Санкт-Петербург: тип. ІІ Отделения собственной Е. И. В. канцелярии, 1830. Т. XXVII. № 20 493. С. 340.

27. О дозволении производить торговлю на ярмарках всем состояниям. Мнение Государственного Совета. 1814. Мая 29. ПСЗ РИ. Собрание первое. Санкт-Петербург: тип. ІІ Отделения собственной Е. И. В. канцелярии, 1830. Т. ХXXII. № 25 594. С. 806-809.
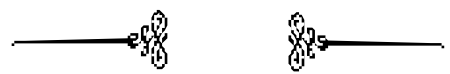
28. О доставлении сведений о ярмарках. Высочайшее повеление, объявленное министром внутренних дел гражданским губернаторам. 1817. Ноября 28. ПСЗ РИ. Собрание первое. Санкт-Петербург: тип. II Отделения собственной Е. И. В. канцелярии, 1830. Т. ХXIV. № 27 167. С. 895.

29. О позволении записываться в купечество во всякое время года. Именной [указ], данный Сенату. 1808. Августа 19. ПСЗ РИ. Собрание первое. Санкт-Петербург: тип. II Отделения собственной Е. И. В. канцелярии, 1830. Т. ХХХІ. № 23 240. С. 543-544.

30. О мерах по взысканию накопившихся по государству недоимок. Сенатский [указ] с изъяснением Комитете министров. 1818. Ноября 7. ПСЗ РИ. Собрание первое. Санкт-Петербург: тип. II Отделения собственной Е. И. В. канцелярии, 1830. Т. XXXV. № 27 572. С. 608-609.

31. О некоторых облегчениях по гильдейским повинностям. Именной [указ], данный Сенату. 1827. Декабря 21. ПСЗ РИ. Собрание второе. Санкт-Петербург: тип. ІІ Отделения собственной Е. И. В. канцелярии, 1830. T. II. № 1 631. C. 1 088-1 090.

32.О облегчении торгующего класса и в особенности мелочных промышленников в платеже подати. Именной [указ], данный Сенату. 1825. Августа 31. ПСЗ РИ. Собрание первое. Санкт-Петербург: тип. II Отделения собственной Е. И. В. канцелярии, 1830. Т. XL. № 30 468. С. 441-442.

33. О писании билетов и контрактов на занятие лавок, погребов и мест во время ярмарок на гербовой бумаге. Сенатский [указ]. 1819. Июня 25. ПСЗ РИ. Собрание первое. Санкт-Петербург: тип. II Отделения собственной Е. И. В. канцелярии, 1830. Т. ХXXVI. № 27 854. С. 243-245.

34. Об устройстве гильдий и о торговле прочих состояний. Дополнительное постановление. 1824. Ноября 14. ПСЗ РИ. Собрание первое. Санкт-Петербург: тип. II Отделения собственной Е. И. В. канцелярии, 1830. Т. XXXIX. № 30 115. С. 588-612.

35. Орлик В. М. Податкова політика Російської імперії в Україні в дореформений період: Монографія. Кіровоград: Імекс-ЛТД, 2007. 631 с.

36. Решетченко Д. В. Правобережна Україна в міжнародній торгівлі зерном наприкінці XVIII - у першій половині ХІХ ст. Украӥнський історичний журнал. 2007. № 4. С. 69-81.

37. Решетченко Д. В. Правобережна Україна в міжнародній торгівлі зерном у 30-40-х рр. ХІХ ст. Проблеми історії Украӥни XIX - початку XX cm. Київ: Інститут історії України НАН України, 2004. Вип. VIII. C. 284-290.

38. Рудченко И. Я. Исторический очерк обложения торговли и промыслов в России, с приложением материалов по торгово-промышленной статистике. Санкт-Петербург: тип. В. Киршбаума, 1893. 492 с.

39. Рындзинский П. Г. Городское гражданство дореформенной России. Москва: Наука: изд-во АН СССР, $1958.559 \mathrm{c}$.

40. Рыдзюнский П.Г. Гильдейская реформа Канкрина. Исторические записки. Москва, 1952. Т. 40. С. 111138.

41. Свод законов Российской империи. Т. ХІ. Ч. 2. Свод уставов и учреждений торговых. Санкт-Петербург, 1832. Кн. 1. 1053 с.

42. Шандра В. С. Генерал-губернаторства в Україні: XIX - початок XX століття. Київ: Інститут історії України, 2005. 427 с.

43. Устав Торговый. Свод законов Российской империи. Санкт-Петербург: тип. II Отделения собственной Е. И. В. канцелярии, 1857. Т. 11. Ч. ІІ. Уставы кредитный, торговый, о промышленности фабричной и заводской, и устав ремесленный. 1239 с.

44. Учреждение Министерства полиции. Манифест.1811. Июня 25. ПСЗ РИ. Собрание первое. СанктПетербург: тип. ІІ Отделения собственной Е. И. В. канцелярии, 1830. Т. XXXI. № 24 687. С. 719-728.

DOI: https://doi.org/10.32782/2305-9389/2020.21.13

УДК 94(477.8):82-94

\section{Анатолій Трембіцький}

\section{Історія Волині в творчих здобутках Свфимія Сіцінського}

В статті висвітлено значний вклад відомого історика, етнографа і краєзнавия Украӥни Свфимія Сіцінського, як бібліо- і історіографа, у вивчення та популяризачію історії Волинського краю, подана коротка характеристика його маловідомих праць із життя населення Волині. Стверджено, щзо у драматичній історії українського народу є величні постаті, яких ніколи не огорне темінь забуття, які завжди будуть з Україною, попри лихоліття і незгоди, байдужість i духовне зубожіння. Саме до таких належить Свфимій Сіиінського, в особі якого, украйнська наука має справжнього знавия української історії, мистеитва, иерковної архітектури, етнографії, археологї, краєзнавства, бібліографії $і$ музейної справи. Небагато знайдеться діячів, які могли б зрівнятися з ним широтою світогляду, багатогранністю інтересів, незгасною жадобою до творчості. Доведено, щңо наукові здобутки Є. Сіцінського, в т. ч. статті-рещензї на
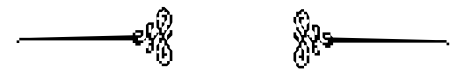